\title{
THE RELATIONSHIP BETWEEN ANTITRUST AND REGULATION IN THE US AND THE EU: CAN LEGAL TRADITION ACCOUNT FOR THE DIFFERENCES?
}

\author{
Amedeo Arena*
}

\begin{abstract}
In the US, federal antitrust law may come into conflict both with federal regulation and regulatory schemes enacted by individual states. Similarly, in the EU, tensions can arise between EU antitrust rules, on the one hand, and either EU or member states' regulation, on the other. This paper seeks to examine the role played by legal tradition, in its manifold dimensions, in shaping the relationship between antitrust and regulation on the two sides of the Atlantic. To this end, Sections 2 and 3 will analyse the statutory provisions and doctrines governing the interplay between antitrust and regulation in the US and the EU. Sections 4 and 5 will explore each jurisdiction's legal traditions that may be relevant to the relationship between antitrust and regulation, such as the constitutional and political context of antitrust policy, the role of legal scholarship, and the antitrust enforcement culture. Section 6 will investigate possible connections between the divergences in the antitrust-regulation interface in the two legal systems and their different legal traditions.
\end{abstract}

\section{Keywords}

Antitrust, regulation, legal tradition

\section{Introduction}

In February 2009, the Supreme Court of the United States of America held that ' $[w]$ hen a regulatory structure exists to deter and remedy anticompetitive harm,

\footnotetext{
LLM (London), LLM (New York), JSD (Naples), Assistant Professor of European Union Law, University of Naples 'Federico II' School of Law. This paper was presented at the Cambridge Journal of International and Comparative Law's Second Annual Conference 'Legal Tradition in a Diverse World', held at the Faculty of Law of the University of Cambridge on 18-19 May 2013. An earlier version of this paper was presented at the American Society of Comparative Law's Eight Annual Workshop, held at the University of Illinois College of Law on 1-2 March 2013. The author wishes to thank participants to both conferences for their valuable feedback. The author is also thankful to Professor Eleanor M Fox (New York University School of Law) and Professor Michael S Jacobs (DePaul University College of Law) for their advice and stimulating critique. The usual disclaimer applies. This article is dedicated to the memory of Rosa D'Elia Arena (1925-2013).
}

Copyright $\odot$ the Author(s).

This work is licensed under a Creative Commons Attribution-NonCommercial-NoDerivs 3.0 License. 
the costs of antitrust enforcement are likely to be greater than the benefits'. Less than two years later, Advocate General Jan Mazák of the European Court of Justice (ECJ) declared: 'the regulatory framework [...] completes competition law provisions and the two sets of rules should be considered to be complementary.' Those statements epitomise the stark divergence in the conceptualisation of the relationship between antitrust and regulation in the United States (US) and the European Union $(E U)$.

The vertical division of powers in those two legal systems adds another layer of complexity. For instance, while the US Supreme Court in Parker v Brown recognised that federal antitrust laws do not prevent states from imposing market restraints 'as an act of government, ${ }^{3}$ the ECJ in Cipolla squarely held that member states must not 'introduce or maintain in force measures, even of a legislative or regulatory nature, which may render ineffective the competition rules applicable to undertakings. 4

This paper seeks to analyse the role of legal tradition, in its manifold dimensions, in shaping the relationship between antitrust and regulation in the US and the EU. To this end, sections I and II of this work will analyse the statutory provisions and doctrines governing the interplay between antitrust and regulation on each side of the Atlantic. Sections III and IV will focus on each jurisdiction's unique legal traditions relevant to the relationship between antitrust and regulation, such as the constitutional and political context of antitrust policy, the role of legal scholarship, and the antitrust enforcement culture. Section V, finally, will investigate possible connections between the divergences in the antitrust-regulation interface in the two legal systems and their different legal traditions.

\section{The antitrust-regulation interface in the US}

In the US, two levels of regulation might conflict, or work side-by-side, with federal antitrust: federal regulation and state regulation. This situation calls for rules on integrating or prioritising federal antitrust law with federal and state regulation. As to the horizontal dimension, express statutory exemptions and judge-made antitrust immunities come into play. The vertical relationship

\footnotetext{
1 Pacific Bell Telephone Co v Linkline Communications, Inc, 555 US 438 (2009) (LinkLine).

2 Case C-280/08 P, Deutsche Telekom AG v Commission, Opinion of AG Mazák, [2010] ECR I-09555, para 19.

3 Parkerv Brown, 317 US 341, 352 (1943).

${ }^{4}$ See Joined Cases C-94/04 and C-202/94, Cipolla and Others [2006] ECR I-11421, para 46 (Cipolla).
} 
between federal antitrust and state regulation, instead, is governed by the state action defence and, to a lesser extent, by the doctrine of federal pre-emption.

\subsection{The horizontal tension: express and implied repeal of antitrust law by regulation}

In the US, the cornerstone federal antitrust provisions are laid down in two Acts of Congress: the Sherman Act (1890) ${ }^{5}$ and the Clayton Act (1914). ${ }^{6}$ Antitrust law has the same rank in the hierarchy of the US system as any other Congressional enactment-including those laying down sectoral regulation. Therefore can repeal or amend the antitrust statutes, ${ }^{7}$ giving rise to antitrust immunities or exemptions. $^{8}$

Repeal of a statute by a later one can be either express or implied. ${ }^{9}$ As to the former, approximately 20 per cent of the US economic activities are expressly exempted from federal antitrust laws. ${ }^{10}$ Federal statutory antitrust exemptions can be divided into 'full exemptions', which exempt a given activity from all antitrust rules, and 'partial exemptions', which grant exemption only from certain antitrust rules. Full exemptions were mostly introduced in a period ranging from the 1907 Bankers' Panic to the mid-1940s. Currently, only five sectors are still exempted: the insurance business, ${ }^{11}$ ocean shipping conferences, ${ }^{12}$

515 USC $\$ 1-7$.

${ }^{6} 15$ USC $\$ 17$

${ }^{7}$ As in other legal orders, it is a well-established principle in US law that the legislature has the power both to enact new laws and that to repeal existing legislation; see District of Columbia $v$ John R Thompson Co, 346 US 100 (1953) and People ex rel Eitel v Lindheimer, 371 Ill 367 (1939).

${ }^{8}$ See generally, L Altman \& M Pollack, Callmann on Unfair Competition, Trademarks and Monopolies (4th edn, 2009) \$4:4; W C Holmes, Antitrust Law Handbook (2009) ch 8; L A Sullivan \& W S Grimes, The Law of Antitrust: an Integrated Handbook (2nd edn, 2006) ch XIV.

9 See Holmes, above $n$ 8, $\$ 8: 6$ ('In cases such as these [...] the immunity is made express by legislative fiat'). In other cases, the Congress expressly states its intention not to repeal antitrust laws by means of specific 'saving clauses' included in regulatory instruments. For instance, $s$ 601(b)(1) of the Telecommunications Act of 1996, 110 Stat 56, 143, reads as follows: "[n]othing in this Act or the amendments made by this Act shall be construed to modify, impair, or supersede the applicability of any of the antitrust laws'.

${ }^{10}$ Altman \& Pollack, above $\mathrm{n} 8, \$ 4: 4$ (the 20 percent figure the authors mention, however, also includes sectors not subject to antitrust laws by judicial exemption).

${ }^{11}$ McCarran-Ferguson Act, c 20, $\$ 2-3$, 59 Stat 33 (1945) (codified as amended at 15 USC \$1012-13 (2006)) (exempting the insurance business insofar as it is regulated by state law and except for acts of boycott, coercion, intimidation, or agreements to that effect).

${ }^{12}$ Shipping Act of 1916, c 451, $\$ 15,39$ Stat 728 (current version at 46 USC $\$ 40307$ (2006)). 
agricultural and dairy farmers cooperatives, ${ }^{13}$ fishermen's associations, ${ }^{14}$ and labour unions. ${ }^{15}$ In view of the broad scope of those immunities, in all five instances the legislature provided for oversight of the exempted sectors through a regulatory scheme enforced by a governmental agency, commission, or board. ${ }^{16}$ The nineteen partial exemptions currently in force, instead, are not accompanied by regulatory oversight of comparable intensity, as they only authorise specific conducts otherwise prohibited by antitrust law. The typical regulatory scheme set out in those statutes consists in an obligation to submit the agreements eligible for exemption to a regulatory authority. ${ }^{17}$

Turning to implied repeal, ${ }^{18}$ the key question is whether Congress, by enacting regulation, had the intention of repealing federal antitrust laws, thus giving rise to implied antitrust immunity. ${ }^{19}$ While immunity has consistently been presumed in cases where federal regulation expressly required a given conduct, ${ }^{20}$ greater uncertainties have arisen when regulation merely authorised a firm's behaviour. ${ }^{21}$ In the past, courts strongly disfavoured implied repeal unless a 'plain repugnancy' could be shown between federal antitrust and regulation. ${ }^{22}$

${ }^{13}$ Capper-Volstead Act, c 57, 42 Stat 388 (1922) (codified at 7 USC \$291-2 (2006)); Clayton Act, c 323, $\$ 6,38$ Stat 730 (1914) (current version at 15 USC $\$ 17$ (2006)); Agricultural Marketing Agreement Act of 1937, c 296, \$3, 50 Stat 246 (current version at 7 USC $\$ 671$ (2006)).

${ }^{14}$ Fishermen's Collective Marketing Act, c 742, \$1, 48 Stat 1213 (1934) (codified at 15 USC $\$ 521$ (2006)).

15 Clayton Act, above n 13, \$6 and 20; Norris-LaGuardia Act, c 90, 47 Stat 70 (1932) (codified at 29 USC $\$ 105$ (2006)).

${ }^{16}$ For instance, the Shipping Act entrusts the Federal Maritime Commission with oversight of industry conduct and endows it with regulatory powers. Likewise, the National Labor Relations Board has regulatory oversight over the matters exempted by Sections 6 and 20 of the Clayton Act and by Section 5 of the Norris-LaGuardia Act.

${ }^{17}$ For instance, the ICC Termination Act demands that the Surface Transportation Board must approve price-fixing agreements concerning the rates of household moves under a 'public interest’ standard. See 49 USC \$13703(a)(2) and USC \$13703(a)(3).

${ }^{18}$ See generally E C Surrette \& G K Harnad, American Jurisprudence (2nd edn, 2009) \$280.

${ }^{19}$ See generally R M Brunell, 'In Regulators we Trust: The Supreme Court's New Approach to Implied Antitrust Immunity' (2012) 78 Antitrust LJ 279.

${ }^{20}$ See United States $v$ National Association of Securities Dealers Inc, 422 US 694, 705 (1975) (National Association of Securities Dealers) (holding that 'if [the relevant statute] obligates appellees to engage in the practices challenged [then it would] necessarily confer antitrust immunity on them.').

${ }^{21}$ See e.g. Gordon v New York Stock Exchange Inc, 422 US 659, 689 (1975) (finding implied immunity because the challenged commission rate practices had been subjected to the scrutiny and approval of the SEC'); but see California v Federal Power Commission, 369 US 482 (1962) (holding that approval of a merger by a federal agency was no bar to antitrust challenge).

${ }^{22}$ See US v Philadelphia National Bank, 374 US 321 (1963); see also National Gerimedical Hospital \& Gerontology Center v Blue Cross of Kansas City, 452 US 378, 388 (1981) (requiring 'convincing 
In Otter Tail Power Co $v$ US, for instance, the US Supreme Court considered that the conflict between regulation and antitrust was not sufficient to trigger antitrust immunity. ${ }^{23}$ Instead, in US $v$ National Association of Securities Dealers the Supreme Court found that the Sherman Act had been displaced by the regulatory scheme established by the Maloney and Investment Company Acts. ${ }^{24}$ One of the factors that may account for such diverging outcomes was the different 'pervasiveness' of the regulatory schemes in question. ${ }^{25}$ More recently, in Credit Suisse, ${ }^{26}$ the Supreme Court held that securities law implicitly precluded antitrust laws, insofar as the application of the latter to the securities markets would entail a substantial risk of errors and inconsistent results that would disrupt the functioning of the securities market. ${ }^{27}$ The Supreme Court also noted that the active enforcement of sector regulation by the Securities and Exchange Commission attenuated the need for antitrust enforcement to address anticompetitive conduct in the securities market. ${ }^{28}$

On other occasions, the Supreme Court limited the scope of antitrust doctrine in cases where regulation was also applicable, even if no implied antitrust immunity could be established. Verizon Communications $v$ Trinko is a case in point. $^{29}$ A local telephone service customer had sued Verizon, the incumbent local service carrier, for failing to provide adequate access to its network to competing carriers with a view of excluding them from the market. Although Verizon was also subject to access obligations pursuant to federal and state regulation, no implied antitrust immunity could be inferred, because federal regulation contained an express saving clause. ${ }^{30}$ Nonetheless, the Supreme Court found that Verizon had no antitrust duty to deal with its competitors under the

showing of clear repugnancy').

${ }^{23}$ See Otter Tail Power Co v US, 410 US 366 (1973) (Otter Tail).

${ }^{24}$ See National Association of Securities Dealers Inc, above $\mathrm{n} 20$.

${ }^{25}$ In Otter Tail, above n 23, 374, the Court noted the legislative history of the Federal Power Act showed that Congress had 'rejected a pervasive regulatory scheme for controlling the interstate distribution of power in favor of voluntary commercial relationships'. Cf National Association of Securities Dealers, above n 20,730-3 ('the investiture of such pervasive supervisory authority in the SEC suggests that Congress intended to lift the ban of the Sherman Act from association activities approved by the SEC').

${ }^{26}$ Credit Suisse Securities (USA) LLC v Billing, 551 US 264 (2007) (Billing).

27 Ibid, 282.

${ }^{28}$ Ibid, 283.

${ }^{29}$ Verizon Communications Inc v Law Offices of Curtis V Trinko LLP, 540 US 398 (2004) (Trinko).

${ }^{30}$ Ibid, 406 (citing 110 Stat 143, 47 USC \$152: 'nothing in this Act or the amendments made by this Act shall be construed to modify, impair, or supersede the applicability of any of the antitrust laws'). 
relevant precedents and noted that, when a regulatory scheme is in place to deter and remedy anticompetitive harm, antitrust enforcement provides no added benefit to competition. ${ }^{31}$ Similarly, in Linkline, it held that an incumbent operator subject to regulatory access obligations imposed by the Federal Communications Commission (FCC) was under no antitrust duty to provide its DSL services at prices that would not squeeze the profit margins of its competitors in the retail market. ${ }^{32}$

Moreover, under the 'filed-rate' doctrine, antitrust does not apply to tariffsetting agreements approved by ('filed with') a federal regulatory agency. ${ }^{33}$ Even though the filed-rate doctrine technically is not an antitrust immunity, ${ }^{34}$ it shares with the latter the concern that antitrust enforcement could yield outcomes at variance with those resulting from the application of the relevant regulatory scheme or agency decisions. ${ }^{35}$

\subsection{The vertical tension: the state action and federal pre-emption doctrines}

As the US is a federal system, not only Congress, but also state legislatures can enact regulation, which might authorise or require conduct prohibited by federal antitrust laws. Courts have developed two doctrines to resolve those tensions: state action and federal pre-emption.

The state action doctrine, commonly referred to as an 'immunity' from federal antitrust claims, is a judicial determination that, by enacting federal antitrust laws, Congress did not intend to challenge action by private parties

\footnotetext{
${ }^{31}$ Ibid, 412.

${ }^{32}$ Linkline, above $\mathrm{n} 1$.

${ }^{33}$ Square D Co v Niagara Frontier Tariff Bureau Inc, 476 US 409, 417 (1986) (dismissing antitrust damages claims brought by private shippers against an association of motor carriers that had collectively set their rates in accordance with joint tariff rates approved by the Interstate Commerce Commission); Utilimax.com Inc v PPL Energy Plus LLC, 378 F.3d 303, 306-7 (3d Cir, 2004); Town of Norwood, Massachusetts v New England Power Co, 202 F.3d 408, 418 (1st Cir, 2000); County of Stanislaus v Pacific Gas and Electrical Co, 114 F 3d 858 ( $9^{\text {th }}$ Cir, 1997).

${ }^{34}$ See Square D Co v Niagara Frontier Tariff Bureau Inc, above n 33, 422 (defendants who engage in anticompetitive activities based on filed rates are still 'subject to scrutiny under the antitrust laws by the Government and to possible criminal sanctions or equitable relief.'); see also Wegoland Ltd $v$ Nynex Corp, 27 F.3d 17, 22 (2d Cir, 1994) ('filed rate doctrine does not leave regulated industries immune from suit under the RICO or antitrust statutes.').

${ }^{35}$ Texas Commercial Energy v TXU Energy Inc, 413 F.3d 503 (5th Cir, 2005) (holding that it was up to the relevant governmental agency, rather than to courts, to determine whether the rates were discriminatory or unlawful).
} 
authorised or required by states. ${ }^{36}$ The Supreme Court first articulated that doctrine in Parker $v$ Brown. ${ }^{37}$ An antitrust suit sought to enjoin Brown, an officer of the state of California, from enforcing a state agricultural proration programme. The Court held that a state is not a 'person' who can violate the Sherman Act and that Congress should not be assumed to deprive states of the right to control their agents.

The threshold question in state action cases is the intensity of the link between the natural or legal person invoking the doctrine and the state: the stronger the connection, the lower the burden of proof required for securing antitrust immunity. Accordingly, state legislatures and judiciaries are per se exempted from federal antitrust laws, without any further scrutiny. For instance, in Hoover $v$ Ronwin the Supreme Court held that a bar testing programme administered by the supreme court of a state plainly qualified for antitrust exemption. ${ }^{38}$ Municipalities, local governmental entities and political subdivisions of the state, instead, bear the burden of proving that their conduct was a foreseeable consequence of 'a clearly articulated policy of the State itself,' approved either by a state legislature or by the state supreme court. ${ }^{39}$ For instance, in FTC $v$ Phoebe Putney Health System Inc, the state action defence failed because Georgia law allowed hospital authorities to acquire hospitals but did not clearly articulate a power to make acquisitions that would substantially lessen competition. ${ }^{40}$ When private parties invoke the state action defence, in addition to a link with a clearly articulated state policy, they must also show that their conduct was subjected to 'active state supervision' to ensure consistency with state policy and to prevent abuse. ${ }^{41}$ The rationale underlying the higher standard of proof applicable to private parties was clearly illustrated by the Supreme Court in Town of Hallie $v$ City of Eau Claire: ' $\mathrm{w}]$ here a private party is engaging in the anticompetitive activity, there is a real danger that he is acting to further his own interests, rather than the governmental

\footnotetext{
36 Ibid.

${ }^{37}$ Parker $v$ Brown, above n 3, 351 ('In a dual system of government in which, under the Constitution, the states are sovereign, save only as Congress may constitutionally subtract from their authority, an unexpressed purpose to nullify a state's control over its officers and agents is not lightly to be attributed to Congress').

38466 US 558, 104 (1984).

${ }^{39}$ Southern Motor Carriers Rate Conference Inc v US, 471 US 48, 63 (1985).

${ }^{40} 663$ F.3d 1369 (11th Cir, 2011).

${ }^{41}$ FTC v Ticor Title Insurance Co, 504 US 621, 631 (1992); Patrick v Burget, 486 US 94, 100-101 (1988); Southern Motor Carriers Rate Conference Inc v US, 471 US 48, 57 (1985); California Retail Liquor Dealers Association v Midcal Aluminum Inc, 445 US 97, 105 (1980) (Midcal).
} 
interests of the State. ${ }^{, 42}$ Determining the intensity of the connection between the defendant and a state is sometimes problematic: for instance, the unsolved conundrum in North Carolina Board of Dental Examiners $v$ FTC, currently pending before the US Supreme Court, is whether an official state regulatory board created by state law may be regarded as a 'private' actor insofar as the majority of its members are also market participants who are elected to their official positions by other market participants. ${ }^{43}$

If the requirements of the state action doctrine are not met, conflicts between federal antitrust laws and state regulatory schemes are solved by recourse to the doctrine of federal pre-emption. That doctrine builds upon the Supremacy Clause set out in the federal Constitution, ${ }^{44}$ according to which, in areas where the federal government is entitled to legislate, federal enactments take precedence over competing exercises of law-making power by states when Congress so intends. ${ }^{45}$ In direct conflict cases, i.e. when state law either demands (as in Calvert) ${ }^{46}$ or validates (as in Midcal) ${ }^{47}$ a conduct prohibited by federal antitrust laws, courts usually follow the 'general' pre-emption approach: as for any other federal statute, they will presume that Congress intended to displace state laws. ${ }^{48}$ Indirect conflict cases, i.e. when state law has anticompetitive effects but does not clearly contradict federal antitrust law, show some interesting features. According to the 'general' pre-emption approach, if a state law stands as an obstacle to the accomplishment of the objectives of a federal statute, Congressional intention to pre-empt that law is presumed. ${ }^{49}$ Conversely, in cases involving state laws contrary to federal antitrust laws, the Court held that, unless a direct conflict can be shown, state law is not pre-empted 'simply because [...] [it] may have an anticompetitive effect. ${ }^{50}$ In Fisher $v$ Berkeley, ${ }^{51}$ for instance, the Court held that a rent control ordinance authorised by a state statute could

\footnotetext{
42471 US 34, 47 (1985).

${ }^{43}$ North Carolina State Board of Dental Examiners v FTC, Case No 13-534. See also 717 F.3d 359, 370 (4th Cir, 2013) ('when a state agency is operated by market participants who are elected by other market participants, it is a "private" actor').

${ }^{44}$ United States Constitution, Art VI $\$ 2$.

${ }^{45}$ US $v$ Gillock, 445 US 360 (1980).

${ }^{46}$ Schwegmann Brothers $v$ Calvert Distillers, 341 US 384 (1951).

${ }^{47}$ Midcal, above n 41.

${ }^{48}$ CSX Transportations Inc. v Easterwood, 507 US 658 (1993).

${ }^{49}$ Three Affiliated Tribes of Fort Berthold Reservation $v$ Wold Engineering, 476 US 877 (1986); Louisiana Public Service Commission v FCC, 476 US 355 (1986).

${ }^{50}$ Rice v Norman Williams Co, 458 US 654, 659 (1982).

51475 US 260 (1986).
} 
not be challenged under federal antitrust law, in spite of its adverse effects on competition. Finally, no conflicts-and, hence, no pre-emption issues-arise when the same conduct is prohibited both by federal antitrust and state laws, even if the latter pursues competition more aggressively than the former. ${ }^{52}$

\section{The antitrust-regulation interface in the EU}

Under EU law, the core antitrust provisions are laid down in Articles 101 and 102 of the Treaty on the Functioning of the European Union (TFEU), ${ }^{53}$ which prohibit, respectively, anticompetitive agreements between undertakings, decisions by associations of undertakings, and concerted practices, as well as abuse of dominant position by one or more undertakings. A number of regulations have been adopted to implement those treaty provisions, including, notably, Council Regulation 1/2003 and Commission Regulation 773/2004/EC.

EU antitrust may come into conflict with EU regulation and national regulation. EU institutions adopt EU regulation in the form secondary legislation. Member states enact national regulation according to their respective constitutional procedures, although in key network industries national regulatory autonomy is significantly constrained by EU regulation adopted to approximate domestic laws.

\subsection{Horizontal tensions: primary law exemptions and the coexistence doctrine}

EU antitrust enjoys a higher rank in the hierarchy of legal sources than any item of EU regulation. Thus, EU regulation cannot repeal Articles 101 and 102 TFEU to establish express or implied exemptions. Exemptions from EU antitrust rules can only be based upon provisions having the same legal force as Articles 101 and 102 TFEU, viz. provisions of EU primary law.

\footnotetext{
52490 US 93 (1989) (dismissing the argument that the federal antitrust principle whereby only first purchasers from the violating monopolist or cartelist can recover treble damages pre-empted state statutes conferring a state cause of action for treble damages also on downstream purchasers).

${ }^{53}$ The EU rules on 'concentrations', instead, are set out in secondary legislation. Merger control was introduced by Council Regulation (EEC) No 4064/89 of 21 December 1989 on the control of concentrations between undertakings [1990] OJ L 73/35 and is currently governed by Council Regulation (EC) No 139/2004 of 20 January 2004 on the control of concentrations between undertakings (the EC Merger Regulation) [2004] OJ L 24/1.
} 
Article 42 TFEU is a case in point. According to that provision, the TFEU rules on competition apply to production of and trade in agricultural products only to the extent determined by the EU legislature. ${ }^{54}$ Sector-specific rules were laid down in Regulation 1184/2006 and Regulation 1234/2007, known as the 'Single Common Market Organization Regulation', which has recently been repealed in the framework of the reform of the Common Agricultural Policy. ${ }^{55}$ The new regulation establishing a common organisation of markets, Regulation 1308/2013, sets out a number of sector-specific provisions concerning the application of competition rules to the agricultural sector. ${ }^{56}$

Similarly, pursuant to Article 305 of the Treaty establishing the European Community (TEC), the provisions of that treaty were without prejudice to the Treaty establishing the European Coal and Steel Community (ECSC). ${ }^{57}$ Accordingly, the coal and steel sector was subject to the specific antitrust provisions set out in the ECSC Treaty. Following the expiry of the ECSC Treaty in July 2002, the Commission issued a communication clarifying that it does not intend to initiate proceedings against agreements previously authorised under the ECSC regime. ${ }^{58}$

Moreover, Article 103(2)(c) TFEU empowers the Council, upon a proposal from the Commission and after consulting the Parliament, to adopt regulations or directives 'to define, if need be, in the various branches of the economy, the scope of the provisions of Articles 101 and 102 [TFEU]'. In the field of transport, that provision enabled the Council to adopt Regulation 169/2009, which exempts technical agreements and agreements concerning the constitution and operation

\footnotetext{
${ }^{54}$ See Case C-311/94, IJssel-Vliet Combinatie BV [1996] ECR I-5023, para 31 ('the common agricultural policy takes precedence over the objectives of the Treaty in the field of competition [...] any application in this field of the Treaty provisions relating to competition is subject to account being taken of the objectives [...] of the common agricultural policy').

${ }^{55}$ Council Regulation (EC) No 1184/2006 of 24 July 2006 applying certain rules of competition to the production of, and trade in, agricultural products [2006] OJ L 214/7, recital 3; Council Regulation (EC) No 1234/2007 of 22 October 2007 establishing a common organisation of agricultural markets and on specific provisions for certain agricultural products (Single CMO Regulation) [2007] OJ L 299/1, recital 84.

${ }^{56}$ With specific regard to antitrust rules, see Regulation (EU) No 1308/2013 of the European Parliament and of the Council of 17 December 2013 establishing a common organisation of the markets in agricultural products and repealing Council Regulations (EEC) No 922/72, (EEC) No 234/79, (EC) No 1037/2001 and (EC) No 1234/2007 [2013] OJ L 347/671, Arts 206-10.

${ }^{57}$ See R Mastroianni, 'Comment to Article 305', in A Tizzano (ed), Trattati dell'Unione Europea e della Comunità Europea (2004) 1367.

58 Communication from the Commission concerning certain aspects of the treatment of competition cases resulting from the expiry of the ECSC Treaty [2002] OJ C 152/5, paras 28-9.
} 
of groupings of small and medium-sized undertakings engaging in road or inland waterway transport. ${ }^{59}$

What if an EU regulation requires or allows a conduct that constitutes a violation of EU antitrust provisions? According to an approach based on the hierarchy of legal sources, EU regulatory measures at variance with the treaties should be declared null and void. To date, however, the ECJ has never annulled an item of EU legislation for a breach of Articles 101 or 102 TFEU. In fact, the ECJ has espoused the so-called co-existence doctrine, according to which EU antitrust and regulation apply side-by-side and undertakings must comply with both of them simultaneously. ${ }^{60}$

Some recent rulings will elucidate the application of that doctrine. In Deutsche Telekom the ECJ held that the circumstance that a national regulatory authority acting in accordance with EU regulation had encouraged a telecoms operator to charge prices that squeezed competitors' margins did not in any way absolve the appellant from responsibility under Article [102 TFEU],', 1 insofar as, in that respect, Article 102 TFEU 'supplement[ed], by an ex post review, the legislative framework adopted by the Union legislature for ex ante regulation of the telecommunications markets. ${ }^{\prime 62}$ Likewise, in AstraZeneca the ECJ held that the fact that EU regulation allowed companies to deregister marketing authorisations for their pharmaceutical products did not rule out the illegality of that conduct under Article 102 TFEU when its sole purpose was that of erecting regulatory barriers to entry against producers of generic drugs. ${ }^{63}$ In that connection, the ECJ noted that 'the illegality of abusive conduct under Article [102 TFEU] is unrelated to its compliance or non-compliance with other legal rules and, in the majority of cases, abuses of dominant positions consist of behaviour which is otherwise lawful under branches of law other than competition law'. ${ }^{64}$ Moreover,

${ }^{59}$ Council Regulation (EC) No 169/2009 of 26 February 2009 applying rules of competition to transport by rail, road and inland waterway [2009] OJ L 61/1. That regulation replaced Regulation (EEC) No 1017/68 of the Council of 19 July 1968 applying rules of competition to transport by rail, road and inland waterway [1968] OJ L 175/1, which laid down an analogous exemption from antitrust rules for agreements in the transport sector.

${ }^{60}$ See Case T-37/92, Bureau Européen des Unions des Consommateurs and National Consumer Council $v$ Commission [1994] ECR II-00285. See also Case 229/83, Leclerc v Au Blé Vert [1985] ECR 1; Case 231/83, Cullet v Leclerc [1985] ECR 305; and Case T-7/92, Asia Motor France v Commission [1993] ECR II-669.

${ }^{61}$ Case C-280/08 P, Deutsche Telekom AG v Commission [2010] ECR I-09555, para 84.

${ }^{62}$ Ibid, para 92.

${ }^{63}$ Case C-457/10 P, AstraZeneca AB and AstraZeneca plc v European Commission (not yet reported), para 154.

${ }^{64}$ Ibid, para 132. 
the Commission's Guidance on Article 102 TFEU and its recent decision in Telefónica suggest that the existence of a regulatory duty to deal may, under certain circumstances, lower the burden of proof required for the imposition of an obligation to supply under Article 102 TFEU. ${ }^{65}$

\subsection{Vertical tensions: the boundaries of EU antitrust rules and judicial balancing.}

According to the doctrine of primacy of EU law, Articles 101 and 102 TFEU, as well as their implementing regulations, take precedence over national rules, ${ }^{66}$ including those of constitutional rank. ${ }^{67}$ National courts ${ }^{68}$ and administrative bodies $^{69}$ are required to construe national law consistently with EU law and to immediately set aside national rules at variance with $\mathrm{EU}$ provisions having direct effect, such as Articles 101 and 102 TFEU. $^{70}$

Therefore, national regulation having anticompetitive effects must be set aside if it may render ineffective the competition rules applicable to undertakings. ${ }^{71}$ According to the ECJ, that is the case where a member state requires or encourages the adoption of agreements, decisions or concerted practices contrary to Article 101 TFEU or reinforces their effects, or where it divests its own rules of the character of legislation by delegating to private economic operators responsibility for taking decisions affecting the economic sphere, or requires or encourages abuses of a dominant position that can jeopardise the full effectiveness of Articles 101 and 102 TFEU. $^{72}$ Accordingly, the ECJ ruled that EU antitrust rules

\footnotetext{
${ }^{65}$ See Communication from the Commission, Guidance on the Commission's enforcement priorities in applying Article 82 of the EC Treaty to abusive exclusionary conduct by dominant undertakings [2009] OJ C 457, para 82; see also Commission Decision of 4 July 2007 relating to a proceedings under Article 82 of the EC Treaty (COMP/38.784, Wanadoo Espana v Telefónica), para 303; Opinion of Advocate General Mázak in Case C-52/09, Konkurrensverket v TeliaSonera AB [2011] ECR I-527, para 58.

${ }^{66}$ Case 6/64, Flaminio Costa v ENEL [1964] ECR (English Special Edition) 585.

${ }^{67}$ Case 11/70, Internationale Handelsgesellschaft mbH $v$ Einfuhr- und Vorratsstelle für Getreide und Futtermittel [1970] ECR 1125, para 3.

${ }^{68}$ Case 26/62, NV Algemene Transport- en Expeditie Onderneming van Gend \& Loos v Netherlands Inland Revenue Administration [1962] ECR (English Special Edition) 1.

${ }^{69}$ Case 103/88, Fratelli Costanzo SpA v Comune di Milano [1989] ECR 1839.

${ }^{70}$ Case 106/77, Amministrazione delle Finanze dello Stato $v$ Simmenthal SpA [1978] ECR 629, paras 22 and 23.

${ }^{71}$ See Cipolla, above n 4, para 46, and Case C-393/08, Sbarigia [2010] ECR I-6337, para 31.

${ }^{72}$ Case C-327/12, Ministero dello Sviluppo economico and Autorità per la vigilanza sui contratti pubblici di lavori, servizi e forniture v SOA Nazionale Costruttori - Organismo di Attestazione SpA (not yet reported), para 38 .
} 
must be interpreted as precluding national provisions associated with agreements between undertakings aimed at fixing air tariffs (Asjes), ${ }^{73}$ prohibiting the granting of rebates (Vlaamse Reisbureaus) ${ }^{74}$ establishing marketing and storage quotas (Aubert), ${ }^{75}$ and fixing business tariffs for customs agents (Commission v Italy). ${ }^{76}$ Failure to establish a direct connection between the contested national measures and specific anticompetitive conducts by undertakings, however, did not prevent the ECJ from reviewing those measures under the TFEU rules on internal market, ${ }^{77}$ which are framed in a way that enables the EU judiciary to strike a balance between the goal of economic integration and the policy objectives pursued by member states. ${ }^{78}$ As a matter of fact, on several occasions the ECJ ruled on the compatibility with the internal market rules without being expressly requested to do so by the referring national court. ${ }^{79}$

Articles 101 and 102 TFEU only apply to undertakings that can freely determine their behaviour on the market. Accordingly, firms cannot be held responsible under EU antitrust rules for conduct that is required by national legislation ${ }^{80}$ or that results from the exercise of an 'irresistible pressure' by a member state ${ }^{81}$ or a non-EU country, ${ }^{82}$ such as the threat of measures that would

\footnotetext{
${ }^{73}$ Joined Cases 209 to 213/84, Criminal proceedings against Lucas Asjes and others [1986] ECR 1425.

${ }^{74}$ Case 311/85, ASBL Vereniging van Vlaamse Reisbureaus v ASBL Sociale Dienst van de Plaatselijke en Gewestelijke Overheidsdiensten [1987] ECR 3801.

${ }^{75}$ Case 136/86, Bureau national interprofessionnel du cognac v Yves Aubert [1987] ECR 4789.

${ }^{76}$ Case C-35/96, Commission of the European Communities v Italian Republic [1998] ECR I-3851.

${ }^{77}$ In Cipolla, above n 4, paras 55-70, the ECJ held that the practice of law relating to minimum rates set by the Italian legislation was compatible with the rules of competition, but could constitute a restriction on the freedom to provide services. It is worth noticing that on several occasions the ECJ gave a preliminary ruling on whether the internal market rules laid down in the TFEU were reviewed compliance of national anticompetitive regulation with the internal market laid down in the TFEU without being expressly requested to do so by the referring court.

${ }^{78}$ See F Ferraro, 'L'efficacia dei principi comunitari sulla concorrenza' (2005) Diritto dell'Unione Europea 669; E Cannizzaro, 'Tecniche di soluzione di conflitti fra politiche dell'Unione' (2013) Diritto dell'Unione Europea 689, 693ff.

${ }^{79}$ See Case 229/83, Association des Centres distributeurs Édouard Leclerc and others $v$ SARL blé vertand others [1985] ECR 1, paras 21-31; Case 231/83, Henri Cullet and Chambre syndicale des réparateurs automobiles et détaillants de produits pétroliers $v$ Centre Leclerc à Toulouse and Centre Leclerc à Saint-Orens-de-Gameville [1985] ECR 305, paras 19-34; Case C-327/12, Ministero dello Sviluppo economico and Autorità per la vigilanza sui contratti pubblici di lavori, servizi e forniture $v$ SOA Nazionale Costruttori (not yet reported).

${ }^{80}$ See Joined Cases C-359/95 P and C-379/95 P, Commission and France v Ladbroke Racing [1997] ECR I-6265, para 33.

${ }^{81}$ See Case T-387/94, Asia Motor France SA and others $v$ Commission [1996] ECR II-961, para 65.

${ }^{82}$ See Commission, Third Report on Competition Policy (1974), para 20.
} 
cause substantial economic harm to the undertaking concerned. The burden of proof for this 'state compulsion' defence is rather high: ${ }^{83}$ an undertaking must show that it was 'deprived of all independent choice in its commercial policy ${ }^{84}$ or that the regulatory scheme suppressed 'any margin of autonomy' on its part. ${ }^{85}$ Similarly, EU competition rules do not apply to sectors where national regulation eliminates any possibility of competitive activity. ${ }^{86}$ Apparently, the only case in which this 'regulatory elimination of competition' defence has been successful is Suiker Unie, ${ }^{87}$ where Italian law had as its object and effect 'to match supply exactly with demand and thereby remove a vital element of normal competition. ${ }^{\text {, }}{ }^{8}$

On other occasions, the ECJ adopted a more nuanced approach to vertical conflicts and was willing to balance the aims of EU antitrust rules against those pursued by national anticompetitive regulation. In Wouters ${ }^{89}$ and Meca-Medina, ${ }^{90}$ for instance, the ECJ agreed to take into account the goals pursued by national regulatory measures, such as the protection of consumers, the proper administration of justice and the fairness of sport competition..$^{91}$ In addition, in Metro, the ECJ held that the stability of the labour market can contribute to improving production' within the meaning of Article 101(3) TFEU and can offset the anticompetitive effects of an agreement between undertakings. ${ }^{92}$ With reference to

\footnotetext{
${ }^{83}$ Joined Cases 240/82, 241/82, 242/82, 261/82, 262/82, 268/82 and 269/82, Stichting Sigarettenindustrie and Others $v$ Commission [1985] ECR 3831, paras 27-9, and Asia Motor France, above n 81, paras 60, 65.

${ }^{84}$ Case T-228/97, Irish Sugar Plc v Commission [1999] ECR II-2969, para 129.

${ }^{85}$ See Asia Motor France, above n 81, para 63.

${ }^{86}$ See Joined Cases 40 to 48, 50, 54 to 56, 111, 113 and 114-73, Coöperatieve Vereniging 'Suiker Unie' UA and others $v$ Commission [1975] ECR 1663, paras 67-72; Case T-387/94, Asia Motor France, above $\mathrm{n}$ 81, para 61; Joined Cases C-359/95 P and C-379/95 P, Ladbroke, above n 80, para 33; Irish Sugar Plc above n 84, para 130.

${ }^{87}$ Suiker Unie, above n 86.

${ }^{88}$ Ibid, para 67.

${ }^{89}$ See Case C-309/99, JCJ Wouters, JW Savelbergh and Price Waterhouse Belastingadviseurs BV $v$ Algemene Raad van de Nederlandse Orde van Advocaten, with the participation of: Balies van de Raad van de Europese Gemeenschap [2002] ECR I-01577, para 97 (Wouters).

${ }^{90}$ See Case C-519/04 P, David Meca-Medina and Igor Majcen v Commission [2006] ECR I-06991, paras $42-5$.

${ }^{91}$ See Wouters, above n 89, para 97 ('[f] or the purposes of application of [Art 101, para 1 TFEU] to a particular case, account must first of all be taken of the overall context in which the decision of the association of undertakings was taken or produces its effects. More particularly, account must be taken of its objectives, which are here connected with the need to make rules relating to organisation, qualifications, professional ethics, supervision and liability, in order to ensure that the ultimate consumers of legal services and the sound administration of justice are provided with the necessary guarantees in relation to integrity and experience [...]').

${ }^{92}$ See Case 26/76, Metro Großmärkte GmbH \& Co. KG v Commission [1977] ECR 1875, para 43. See
} 
Article 102 TFEU, the ECJ has recognised that the ownership of exclusive rights granted by national IP legislation cannot in itself constitute an abuse of a dominant position, ${ }^{93}$ albeit the exercise of such rights may be deemed abusive in 'exceptional circumstances. ${ }^{94}$

The ECJ also resorted extensively to balancing in connection with Article 106(2) TFEU, which grants a conditional derogation from the rules of the EU treaties to firms entrusted with the operation of Services of General Economic Interest (SGEIs) insofar as the application of those rules could obstruct the performance of general interest tasks assigned to those firms. The outcome of judicial balancing between the EU goal of undistorted competition and national policies ${ }^{95}$ has often been in favour of member states. ${ }^{96}$ Indeed, the ECJ has granted member states a broad discretion to define what services should be considered of general economic interest (the principle of 'freedom of definition'). ${ }^{97}$ In addition, the ECJ has progressively taken a more permissive approach in assessing the proportionality of the measures taken by member states derogating from the rules of competition. In early cases, the ECJ only consented to such measures in cases of absolute incompatibility between the

also Joined Cases T-528/93, T-542/93, T-543/93 and T-546/93, Metropole Télévision SA and Italian Television Networks SpA and Gestevisión Telecinco SA and Antena 3 de Televisión v Commission [1996] ECR II-649, para 118 ('the Commission is entitled to base itself on considerations connected with the pursuit of the public interest in order to grant exemption under Article [101(3) TFEU]').

${ }^{93}$ See Joined Cases C-241/91 P and C-242/91 P, Telefis Radio Eireann (RTE) and Independent Television Publications Ltd (ITP) v Commission [2005] ECR I-743, para 46.

${ }^{94}$ See Case 238/87, Volvo AB v Erik Veng (UK) Ltd [1988] ECR 6211, para 7; Case C-418/01, IMS Health $\mathrm{GmbH} \& \mathrm{Co} \mathrm{OHG} v$ NDC Health GmbH \& Co KG [2004] ECR I-05039, paras 34-5.

${ }^{95}$ See Case C-202/88, France v Commission [1991] ECR I-1223, para 12 (holding that Art 106(2) TFEU 'seeks to reconcile the Member States' interest in using certain undertakings, in particular in the public sector, as an instrument of economic or fiscal policy with the Community' s interest in ensuring compliance with the rules on competition and the preservation of the unity of the Common Market').

${ }^{96}$ See Case C-67/96, Albany International BV v Stichting Bedrijfspensioenfonds Textielindustrie [1999] ECR I-05751, paras 102-23 (social policy); Case C-266/96, Corsica Ferries France SA v Gruppo Antichi Ormeggiatori del Porto di Genova Coop, arl and Others [1998] ECR I-03949, paras 42-7 (universal mooring service); Joined Cases C-147/97 and C-148/97, Deutsche Post AGv GZS Gesellschaft für Zahlungssysteme mbH) and Citicorp Kartenservice GmbH [2000] ECR I-825, paras 51-66.

${ }^{97}$ See Case C-157/94, Commission v Netherlands [1997] ECR I-5699, para 40 ('Member States [...] cannot be precluded, when defining the services of general economic interest which they entrust to certain undertakings, from taking account of objectives pertaining to their national policy or from endeavouring to attain them by means of obligations and constraints which they impose on such undertakings'). 
application of the competition rules and the performance of the general interest tasks assigned to firms. ${ }^{98}$ More recently, instead, the ECJ has taken the view that, in order to trigger the exemption under Article 106(2) TFEU, it is not necessary to prove that very survival of the company would be threatened ${ }^{99}$ and no other conceivable measure-which by definition would be hypothetical-could enable the fulfilment of the mission of general interest under the same conditions. ${ }^{100}$

\section{Legal tradition in the US}

\subsection{Constitutional and political context of antitrust policy}

The Sherman Act and the Clayton Act were not enacted in a legal vacuum. They entered into force in a legal order based on a constitution that was ordained and established by a unitary demos, the 'People of the United States.'101 The political unity of the American nation and the broad powers conferred by the Constitution on the federal government allowed the creation of a common regulatory framework for essential infrastructures, ${ }^{102}$ a common currency, ${ }^{103}$ and other conditions that enabled a number of nation-wide corporations to flourish. ${ }^{104}$ The increasing concentration of market power, ${ }^{105}$ however, began to be perceived as a threat not only to economic order, but also to individual freedom

${ }^{98}$ See Case 155/73, Giuseppe Sacchi [1974] ECR 409, para 15; Case C-41/90, Klaus Höfner and Fritz Elser v Macrotron GmbH [1991] ECR I-1979, para 24; Case 311/84, Centre d'études de marchétélémarketing (CBEM) v SA Compagnie de luxembourgeoise Télédiffusion (CLT) and Information publicité Benelux SA (IPB) [1985] ECR 3261, para 17.

${ }^{99}$ See Commission v Netherlands, above n 97, para 43.

${ }^{100}$ Ibid, para 58; see also Case C-159/94, Commission v France [1997] ECR I-05815, para 101.

${ }^{101}$ See J H H Weiler, 'Federalism Without Constitutionalism: Europe's Sonderweg', in K Nicolaidis \& R Howse (eds), The Federal Vision: Legitimacy and Levels of Governance in the US and the EU (2001) 53-69. But see M Rosenfeld, 'The European Convention and Constitution Making in Philadelphia' (2003) 1 Int J Const L 373, 375 (arguing that 'the people behind the 1787 American constitution were profoundly divided and, for the most part, not yet formed').

${ }^{102}$ For instance, three years prior to the enactment of the Sherman Act, Congress had passed the Interstate Commerce Act of 1887, c 104, 24 Stat 379, to regulate the railroad industry.

${ }^{103}$ See United States Constitution, Art I \$8(5). See also McCulloch v Maryland, 17 US (4 Wheat) 316 (1819) (holding that Congress may charter banks and endow them with the right to issue circulating notes); Veazie Bank v Fenno, 75 US (8 Wall) 533 (1869) (finding that Congress may restrain the circulation of notes not issued under its own authority).

${ }^{104}$ See e.g. V Dagnino, I cartelli industriali naizonali e internazionali (1928) 131; L F Pace, I fondamenti del diritto antitrust europeo (2005) 9.

${ }^{105}$ See Standard Oil of New Jersey v United States, 221 US 1, 50 (1911) (summarising the conditions that led to the enactment of federal antitrust laws). 
and democracy. ${ }^{106}$ Therefore, just as seventeen states had introduced antitrust laws, ${ }^{107}$ Congress resolved to pass legislation designed to attain 'an organization of industry in small units' in competition with one another, ${ }^{108}$ a goal that was subsequently replaced with that of consumer welfare under the influence of the Chicago School. ${ }^{109}$

The enactment of antitrust laws in the form of federal statutes appeared appropriate to attain those objectives. Antitrust and regulation were alternative instruments in the hands of the federal government to pursue its economic policy. Statutory antitrust exemptions, therefore, have reflected the ebb and flow of governmental intervention and the changing political landscape. ${ }^{110}$ During the Great Depression, for instance, in order to create 'stability' and to protect national industries, the Congress passed the National Industrial Recovery Act (NIRA), which allowed firms to create 'codes of fair competition' that effectively encouraged coordinated conduct in several major industrial sectors (e.g. lumber, steel, oil, mining, and automobiles). ${ }^{111}$ In 1935, however, the US Supreme Court struck down the NIRA as unconstitutional and Congress never replaced its provisions. ${ }^{112}$

Also the judicial transition from 'clear repugnancy' to 'soft immunity' in the area of implied antitrust exemptions reflects, to a degree, the changing political attitude in respect of antitrust. While the Supreme Court initially regarded federal antitrust laws as having quasi-constitutional status ${ }^{113}$-in Northern Pacific Railway it even referred to the Sherman act as the 'charter of economic freedom'114 -in more recent cases it appeared to consider them just another instance of federal legislation, enjoying no particular prevalence over sectoral regulation. ${ }^{115}$

\footnotetext{
${ }^{106}$ See H Schweitzer, 'Parallels and Differences in the Attitudes towards Single-Firm Conduct: What are the Reasons? The History, Interpretation and Underlying Principles of Sec. 2 Sherman Act and Art 82 EC' (EUI Working Paper No 2007/32) 6.

${ }^{107}$ See G J Stigler, 'The Origin of the Sherman Act' (1985) 14 J Leg Stud 1, 6 (providing a table of state antitrust laws by year of passage).

${ }^{108}$ See United States $v$ Aluminium Co of America, 148 F.2d 416, 429 (2d Cir, 1945).

${ }^{109}$ See H Hovenkamp, The Antitrust Enterprise: Principle and Execution (2005) 31.

${ }^{110}$ See C A Varney, Assistant Attorney General, US Department of Justice, 'Vigorous Antitrust Enforcement in this Challenging Era', 11 May 2009, 2-5, available at <http://www.usdoj.gov/atr/public/speeches/245711.pdf> [accessed 5 April 2014].

${ }^{111}$ Pub L 73-90, 48 Stat 195, enacted 16 June 1933, codified at 15 USC $\$ 703$.

${ }^{112}$ Schechter Poultry Corporation v United States, 295 US 495 (1935).

${ }^{113}$ See Appalachian Coals Inc v United States, 288 US 344, 359-60 (1933) (comparing the Sherman Act to a constitutional provision).

${ }^{114}$ See Northern Pacific Railroad Co v United States, 356 US 1, 4 (1958).

${ }^{115}$ See Trinko, above n 29, 415-16 (2004) ('The Sherman Act is indeed the "Magna Carta of free
} 
Another key variable in the vertical tension between federal antitrust and state regulation is the American understanding of federalism as a polity in which states retain a residuary and inviolable area of sovereignty. ${ }^{116}$ At the beginning of America's federal experience, the US Constitution expressly enumerated the powers granted by the people to the federal government, ${ }^{117}$ resulting in a government of limited, enumerated, and delegated powers. ${ }^{118}$ Although successive centrifugal and centripetal trends have occurred since the drafting of the Federal Constitution, the words 'to form a more perfect Union' set out in its Preamble emblematically capture a static vocation to 'preserve' and 'maintain' a given vertical division of powers. ${ }^{119}$

The relationship between federal antitrust laws and state regulation was profoundly influenced by the need to accommodate the potentially far-reaching scope of federal antitrust laws with a polity based on a model of 'dual federalism.' ${ }^{120}$ A formal application of the pre-emption doctrine to federal antitrust laws would have entailed significant risks of encroachment on state sovereignty, as most state enactments, such as those authorising or encouraging concerted pricing practices, either directly clash with federal antitrust laws or stand as an obstacle to the accomplishment of the aims pursued by Congress. ${ }^{121}$

It is thus for the sake of a well-balanced federalism that the Supreme Court in Parker $v$ Brown introduced the state action doctrine, paving the way for a broad antitrust exemption covering anticompetitive conducts authorised or required

enterprise”, but 'it does not give judges carte blanche to insist that a monopolist alter its way of doing business whenever some other approach might yield greater competition') (citation omitted).

${ }^{116}$ See United States Constitution, Amendment X ('The powers not delegated to the United States by the Constitution, nor prohibited by it to the States, are reserved to the States respectively, or to the people'). Cf Articles of Confederation, Art II ('Each state retains its sovereignty, freedom, and independence, and every power, jurisdiction, and right, which is not by this Confederation expressly delegated to the United States, in Congress assembled').

${ }^{117}$ United States Constitution, Art I $\$ 8$.

${ }^{118}$ See e.g. New York v United States, 505 US 144 (1992); Bute v Illinois, 333 US 640 (1948).

${ }^{119}$ See Carter $v$ Carter Coal Co, 298 US 238, 295 (1936) (stating that there can be no loss of autonomy to the states through their union under the Constitution since ' $\mathrm{t}$ ] he preservation of the States, and the maintenance of their governments, are as much within the design and care of the Constitution as the preservation of the Union and the maintenance of the National government').

${ }^{120}$ See R Schütze, From Dual to Cooperative Federalism: The Changing Structure of European Law (2009) 5 ('Dual federalism is based on the idea of dual "sovereignty". The Constitution divides sovereignty into blocks of exclusive powers. The federal government and the State governments are co-equals and operate independently in their separate spheres').

${ }^{121}$ See L A Sullivan \& W S Grimes, The Law of Antitrust: An Integrated Handbook (2006) 800. 
by state laws. ${ }^{122}$ Moreover, outside the boundaries of state action, the Supreme Court has applied a weaker version of its standard pre-emption analysis, by confining the displacement of state regulation to cases of direct conflict with federal antitrust law. ${ }^{123}$

\subsection{Legal scholarship and antitrust enforcement tradition}

American legal scholarship has significantly influenced the judicial conceptualisation of the antitrust-regulation interface. Harvard School and Chicago School provided three powerful arguments employed by the Supreme Court to justify the retrenchment of antitrust in regulated industries.

First, a Chicago School scholar, Frank Easterbrook, introduced error-cost analysis in antitrust enforcement. He argued that, since antitrust enforcers are often unable to distinguish between anticompetitive and innocuous conduct, they risk identifying false positives, thus 'chill[ing] the very conduct the antitrust laws are designed to protect. ${ }^{124}$ In his view, false positives are worse than false negatives, ${ }^{125}$ which are spontaneously corrected by the market in the long run. ${ }^{126}$ The Supreme Court expressly relied upon the risk of false positives as an argument to shrink the scope of monopolisation claims in Trinko. ${ }^{127}$

Second, in a frequently cited essay, Harvard School Professor Philip Areeda submitted that courts should not impose antitrust remedies that they cannot monitor, especially when doing so requires courts 'to assume the day-to-day controls characteristic of a regulatory agency.' ${ }^{\text {. }}$ Justice Scalia's opinion for the

\footnotetext{
${ }^{122}$ See Parker v Brown, above n 3, 351 ('In a dual system of government in which, under the Constitution, the states are sovereign, save only as Congress may constitutionally subtract from their authority, an unexpressed purpose to nullify a state's control over its officers and agents is not lightly to be attributed to Congress').

${ }^{123}$ See e.g. Schwegmann Brothers v Calvert Distillers, 341 US 384 (1951); Midcal, above n 41.

${ }^{124}$ See Matsushita Electrical Industrial Co v Zenith Radio Corp, 475 US 574, 594 (1986).

${ }^{125}$ See F H Easterbrook, 'The Limits of Antitrust' (1984) 63 Texas LR 1, 16 ('Other things equal, we should prefer the error of tolerating questionable conduct, which imposes losses over a part of the range of output, to the error of condemning beneficial conduct, which imposes losses over the whole range of output.').

${ }^{126} \mathrm{Ibid}, 15$ (claiming that monopoly profits incentivise market entry that may offset the detrimental effects of undetected anticompetitive conduct).

${ }^{127}$ Trinko, above n 29, 414 ('Against the slight benefits of antitrust intervention here, we must weigh a realistic assessment of its costs. [...] The cost of false positives counsels against an undue expansion of $\$ 2$ liability’).

${ }^{128}$ See P Areeda, 'Essential Facilities: An Epithet in Need of Limiting Principles' (1989) 58 Antitrust LJ 841, 853.
} 
Court in Trinko expressly quoted a passage from that essay before reaching the conclusion that an antitrust court would have been unable to enforce the access to the local loop obligations that the respondent had requested. ${ }^{129}$ Similarly, in LinkLine the Supreme Court conceded that courts would have been unable to correctly assess price-squeeze claims without conducting 'complex proceedings like rate-setting agencies.' ${ }^{, 130}$

Last but not least, a former Harvard School scholar, Stephen Breyer, was the Chief Judge of the Court of Appeals (1st Circuit) that handed down the opinion in Town of Concord, according to which 'antitrust analysis must sensitively recognize and reflect the distinctive economic and legal setting of the regulated industry to which it applies. ${ }^{131}$ That holding was directly instrumental for the Supreme Court in Trinko in reaching the conclusion that antitrust enforcement provides no additional benefit when a regulatory structure is in place. ${ }^{132}$ Stephen Breyer also expressly recalled that holding in his concurrence in LinkLine as an argument against the recognition of price-squeeze claims under Section 2 of the Sherman Act. ${ }^{133}$ Moreover, in Credit Suisse the Supreme Court expressly stated that the Security Exchange Commission's active enforcement of sector regulation made it 'somewhat less necessary to rely on antitrust actions to address anticompetitive behavior' in the securities market. ${ }^{134}$

Another factor that might have affected the relationship between federal antitrust laws and federal regulation is the US private antitrust enforcement culture. In order to encourage private parties to enforce antitrust laws, the latter provide powerful incentives such as mandatory treble damages, asymmetric shifting of costs, broad discovery rights, class actions, and jury trials. It is thus no wonder that most claims against dominant firms under Section 2 of the Sherman act have been brought by private plaintiffs rather than by public

\footnotetext{
${ }^{129}$ Trinko, above n 29, 415 ("We think that Professor Areeda got it exactly right: "No court should impose a duty to deal that it cannot explain or adequately and reasonably supervise" [...] An antitrust court is unlikely to be an effective day-to-day enforcer of these detailed sharing obligations').

${ }^{130}$ Linkline, above n 1, 453.

${ }^{131}$ Concord v Boston Edison Co, 915 F.2d 17, 22 (1st Cir, 1990).

${ }^{132}$ Trinko, above n 29, 411-12 ('One factor of particular importance is the existence of a regulatory structure designed to deter and remedy anticompetitive harm. Where such a structure exists, the additional benefit to competition provided by antitrust enforcement will tend to be small, and it will be less plausible that the antitrust laws contemplate such additional scrutiny').

${ }^{133}$ Linkline, above n 1, 459 (Stevens J).

${ }^{134}$ Billing, above n 26, 283.
} 
enforcers. ${ }^{135}$ Fearing that firms could be over-deterred by the prospect of private actions, but unable to expunge those incentives from the private enforcement system, courts have reacted by applying stricter liability standards so as to reduce private plaintiffs' chances of success. ${ }^{136}$ As Hovenkamp put it 'judges respond[ed] to an overly aggressive remedies system by defining substantive violations too narrowly.' 137

An analogous process of judicial 'equilibration'138 may have taken place at the antitrust-regulation intersection: as firms could be over-deterred by the concurrent application of antitrust and regulation, courts shrunk the scope of antitrust claims where concurrent regulatory remedies were available. In Trinko, for instance, the incumbent local exchange carrier Verizon had already been fined twice by state and federal regulators for its conduct against its competitor AT\&T. ${ }^{139}$ Accordingly, the majority ruled that, on that occasion, the applicable regulatory regime had been 'an effective steward of the antitrust function.'.40 In Credit Suisse, as noted above, the Supreme Court expressly recognised that, because of sector regulation and its active enforcement by the US Securities and Exchange Commission (SEC), there was 'a diminished need for antitrust enforcement to address anticompetitive conduct. ${ }^{141}$

\footnotetext{
${ }^{135}$ The Supreme Court heard the first case concerning the interpretation of Section 2 of the Sherman Act involving the federal government as plaintiff as late as in 1973; see Otter Tail, above n 23, 366 .

${ }^{136}$ See W E Kovacic, 'Private Participation in the Enforcement of Public Competition Laws' in M Andenas et al (eds), Current Competition Law, vol 2 (2004) 167; W E Kovacic, 'Competition Policy in the European Union and the United States: Convergence or Divergence?' (Speech at the Fifth Annual Antitrust Conference, 2 June 2008), <http://www.ftc.gov/speeches/kovacic/080602bateswhite.pdf> [accessed 9 October 2013] (claiming that judicial fears that the US style of private rights of action [...] excessively deter legitimate conduct have spurred a dramatic retrenchment of antitrust liability standards' for unilateral conduct by dominant firms).

${ }^{137}$ Hovenkamp, above n 109, 76.

${ }^{138}$ See S Calkins, 'Summary Judgment, Motions to Dismiss, and Other Examples of Equilibrating Tendencies in the Antitrust System' (1986) 74 Geo LJ 1065 (applying the concept of equilibrating tendencies to antitrust system's treatment of private treble damage claims).

${ }^{139}$ Trinko, above n 29, 413 ('The FCC soon concluded that Verizon was in breach of its sharing duties [...], imposed a substantial fine, and set up sophisticated measurements to gauge remediation, with weekly reporting requirements and specific penalties for failure. The PSC [...] imposed additional financial penalties and measurements with daily reporting requirements').

${ }^{140}$ Ibid.

${ }^{141}$ Billing, above n 26, 284.
} 


\section{$5 \quad$ Legal tradition in the EU}

\subsection{Constitutional and political context of antitrust policy}

The EU antitrust rules laid down in the Treaty of Rome (1957) came to the light in a completely different setting from that in which US federal antitrust laws were enacted. As witnessed by the multiple references in that treaty to the 'peoples' of Europe, in the 1950s there was no unitary European demos. ${ }^{142}$ The political discord of the peoples of Europe, which had already caused two world wars, had resurfaced three years earlier when the French parliament refused to ratify the European Defence Community Treaty, thus nipping in the bud the prospect of a European Political Community. It became clear that European integration could not be premised on political grounds.

The European founding fathers thus reverted to the strategy outlined a few years earlier in the Schuman declaration: 'setting up of common foundations for economic development as a first step in the federation of Europe. ${ }^{143}$ The Spaak Report of 1956, which is generally regarded as the blueprint of the Treaty of Rome, stated that the merging of national markets into a common market was an 'absolute necessity' to reap the benefits of comparative advantage and to allow European companies to exploit economies of scale. ${ }^{144}$ To that end, the report recommended a ban on protectionist measures by member states and the introduction of competition provisions directly addressed to undertakings. ${ }^{145}$ The competition provisions not only outlawed cartels, which had been a catalyst of the economic rivalries between European nations that had sparked the two world wars, but also prevented European firms from restoring, by way of market-sharing agreements, the insulation of markets pursued by national protectionist policies. ${ }^{146}$

Since undistorted competition was instrumental to the establishment of the common market-which, in turn, constituted the main objective of European integration - the drafters of the Treaty of Rome granted antitrust provisions the status of primary law by including them in the EEC Treaty, ${ }^{147}$ along with prohibitions addressed to member states, such as those on custom duties,

\footnotetext{
${ }^{142}$ See Weiler, above $\mathrm{n} 101,53,66$.

${ }^{143}$ Emphasis added.

${ }^{144}$ Intergovernmental Committee of the Messina Conference, Report of the Heads of Delegation to the Ministers of Foreign Affairs (1956) 13 (Spaak Report).

${ }^{145}$ Ibid, $53 \mathrm{ff}$.

${ }^{146}$ See Pace, above n 104, 57; G Strozzi \& R Mastroianni, Diritto dell'Unione Europea (2013) 2.

${ }^{147}$ See Arts 85 and 86 of the EEC Treaty (currently Arts 101 and 102 TFEU).
} 
quantitative restrictions, discriminatory internal taxation etc.. The task of complementing the general provisions laid down in the EEC Treaty with detailed horizontal or sectoral regulation was entrusted to the Council, which acted upon proposals from the Commission.

The rank of antitrust vis-à-vis regulation in the hierarchy of EU legal sources effectively shielded the former from repeal by the latter, thus preventing member states acting within the Council from taking back the competences conferred on the EU ('re-delegation'). ${ }^{148}$ Indeed, although the momentum for market integration has occasionally faltered and antitrust itself has faced direct political opposition from time to time, ${ }^{149}$ the burdensome procedures required for the amendment of the Treaties have enabled antitrust provisions to come through virtually unscathed for over half a century. ${ }^{150}$

Moving from the assumption that the peoples of Europe were separate and diverse, the Treaty of Rome sought to create 'an ever closer union' among them. ${ }^{151}$ Rather than envisaging a fixed division of the competences between the Community and its member states, the Treaty laid down a list of Community objectives and the means to pursue them with the cooperation of member states. No area was a priori excluded from the purview of European integration. As a matter of fact, a catalogue of EU competences was introduced only fifty years later by the Treaty of Lisbon.

Although member states were required to facilitate the achievement of the Community's objectives, ${ }^{152}$ resistance at the national level was expected, insofar as market integration often interfered with rent positions created by national regulation. Accordingly, the drafters entrusted the enforcement of antitrust provisions to the Commission, an independent institution designed to

\footnotetext{
${ }^{148}$ See M Waelbroeck, 'The Emergent Doctrine of Community Pre-emption-Consent and Redelegation', in T Sandalow \& E Stein (eds), Courts and Free Markets: Perspectives from the United States and Europe, vol 2 (1982) 548-80.

${ }^{149}$ Political opposition by France's President Nicholas Sarkozy to competition policy resulted in the relocation of the goal of undistorted competition from the body of the Treaties to Protocol no. 27 attached to the Treaty of Lisbon.

${ }^{150}$ But see N E Farantouris, 'La fin de la concurrence non faussée après le traité réformateur' (2009) 524 Revue du Marché commun et de l'Union européenne 41 (questioning whether the goal of undistorted competition will be referred to in the same way and with the same frequency, following its relocation 'extra muros'); P Fabbio, 'Funzioni e ancoraggi apicali del diritto antitrust' (2013) 22 Annali italiani del diritto d'autore della cultura e dello spettacolo 228-30 (arguing that the establishment of the common market is no longer a 'categorical imperative' of EU competition law).

${ }^{151}$ See recital 1 of the Preamble to the EEC Treaty (currently recital 1 of the Rreamble to the TFEU).

${ }^{152}$ See EEC Treaty, Art 5.
} 
advance economic integration without interference from national governments and politics in general. ${ }^{153}$ Moreover, they granted the Commission the monopoly over legislative initiative to propose the measures that define the scope of EU antitrust rules ${ }^{154}$ and the extent to which they apply to agricultural products. ${ }^{155}$

\subsection{Legal scholarship and antitrust enforcement tradition}

The development of EU antitrust law was deeply influenced by Ordo-liberalism (the so-called 'Freiburg School'), which advocated a polity based on freedom and autonomy of individuals and firms within the framework of a constitutional democracy based upon the rule of law. ${ }^{156}$ The experience with laissez-faire policies at the turn of the 20th century, however, had shown that market economy left to its own devices would eventually lead to the concentration of economic power in private hands, ${ }^{157}$ which constituted a major threat to the free economic order advocated by ordo-liberals. ${ }^{158}$

Freiburg School scholars, therefore, did not regard markets as self-correcting, but rather as fragile creatures ${ }^{159}$ to be preserved by vigorous antitrust enforcement and, in the case of natural monopolies, even price regulation. ${ }^{160}$ But how could such a far-reaching antitrust intervention be reconciled with the risk of error due to information asymmetries? The EU solution to that conundrum was to shift the burden over to firms, which had easier access to information concerning their own cost structures and market position than public enforcers. ${ }^{161}$ In the context of Article 102 TFEU, this model was conceptualised in terms of a 'special responsibility' borne by dominant firms to ensure that their market conduct did not harm competition. In AstraZeneca and Deutsche Telekom, the ECJ relied upon the 'special responsibility' argument to justify dominant firms' duty

\footnotetext{
${ }^{153}$ See EEC Treaty, Art 89.

${ }^{154}$ See EEC Treaty, Art 87(2)(c).

${ }^{155}$ See Arts 42 and 43 of the EEC Treaty.

${ }^{156}$ See W Eucken, Die Grundlagen der Nationalokonomie (5th edn, 1947) 175-9.

${ }^{157}$ See W Eucken, 'Das Problem der wirtschaftlichen Macht', in Wirtschaftsmacht und Wirtschaftsordnung (2001) 9.

${ }^{158}$ Ibid, 22; See also F Böhm, 'Die Idee des Ordo im Denken Walter Euckens', in E J Mestmäcker (ed), Freiheit und Ordnung in der Marktwirtschaft (1980) 73-4.

${ }^{159}$ See P Larouche \& M P Schinkel, 'Continental Drift in the Treatment of Dominant Firms: Article 102 TFEU in Contrast to Section 2 Sherman Act' (TILEC Discussion Paper 2013-020) 9-10, $<$ http://ssrn.com/abstract=2293141> [accessed 6 April 2014].

${ }^{160}$ See W Eucken, Grundsatze der Wirtschaftspolitik (7th edn, 2004) 297; L Miksch, 'Die Wirtschaftspolitik des Als-Ob' (1948-1949) 105 Zeitschrift fur die gesamte Staatswissenschaft 310, 331-333.

${ }^{161}$ Larouche \& Schinkel, above n 159, 13-18.
} 
to pro-actively self-assess their conduct, even beyond the requirements of sector regulation. ${ }^{162}$

In spite of recent attempts to encourage the development of private actions, ${ }^{163}$ the enforcement of antitrust provisions in the EU has been predominantly carried out by the Commission and by national antitrust authorities. EU courts have not been troubled by over-deterrence concerns and, accordingly, have not felt the need to 'equilibrate' the system by raising the standard of antitrust liability in markets subject to regulation. ${ }^{164}$ Moreover, the predominance of public enforcement affords the Commission a substantial first-mover's advantage in determining which cases reach EU courts, thus allowing the Commission to influence the development of the EU jurisprudence on the antitrust-regulation interface.

\section{Findings and comparative assessment}

The analysis of the relationship between antitrust and regulation in the US and in the EU highlights several significant divergences. The first and most apparent one involves express antitrust exemptions. In the US, Congress carved out broad exemptions from federal antitrust laws accounting for as much as 20 per cent of that nation's economy. In the EU, on the other hand, antitrust exemptions must be based on primary law and cover fewer and narrower sectors.

The second point of divergence is the judicial approach to the horizontal tensions between antitrust and regulation. The Supreme Court's holdings in Trinko, Linkline and Credit Suisse show an overall willingness to defer to federal regulation when it intersects federal antitrust laws. Federal antitrust and federal regulation are conceived, in essence, as mutually exclusive legal regimes. In contrast, the ECJ rulings in Deutsche Telekom and AstraZeneca suggest that EU antitrust and EU regulation are complementary regimes, which apply side-by-side even when the former prohibits conduct authorised by the latter.

\footnotetext{
${ }^{162} \mathrm{Ibid}, 15$.

${ }^{163}$ See Proposal for a Directive of the European Parliament and of the Council on certain rules governing actions for damages under national law for infringements of the competition law provisions of the Member States and of the European Union, 11 June 2013, COM(2013) 404; Communication from the Commission on quantifying harm in actions for damages based on breaches of Article 101 or 102 of the Treaty on the Functioning of the European Union [2013] OJ C 167/19.

${ }^{164}$ See W E Kovacic, 'Competition Policy in the European Union and the United States: Convergence or Divergence', in X Vives (ed), Competition Policy in the EU: Fifty Years on from the Treaty of Rome (2009) 326-7.
} 
In fact, the Commission's Guidance on Article 102 TFEU and its Telefónica decision suggest that the existence of a regulatory duty to deal may, under certain circumstances, facilitate the imposition of certain antitrust remedies.

The third divergence concerns the judicial approach to the vertical dimension of the antitrust-regulation interface. The US state action doctrine involves a broad and generalised deference to state regulation, so long as a sufficient link can be shown between the defendant and a state policy. Even if the requirements for state action immunity are not met, US courts have appeared willing to allow state regulation having anticompetitive effects to coexist with federal antitrust laws in the absence of direct conflicts between the two regimes. In the EU, on the other hand, firms can escape responsibility under EU antitrust law only if they prove that their conduct was compelled by national regulation or that the latter eliminated competition altogether. Anticompetitive national measures must be immediately set aside if they are linked to a specific conduct by undertakings contrary to competition law; otherwise, national measures having anticompetitive effects can be subject to judicial balancing by the ECJ.

Several factors have been suggested to account for such divergences. The political unity of the American 'people' has enabled federal antitrust to focus exclusively on constraining market power and, at a later stage, on enhancing consumer welfare. Conversely, the division of the European demoi has induced EU competition law to take on the objective of establishing a common market. Accordingly, while antitrust and regulation in the US were conceived as alternative policy instruments in the hands of the federal government, in the EU competition rules were given the rank of primary law to prevent them from being repealed by regulation enacted by the member states-driven Council. The enforcement of antitrust rules was entrusted to a supranational body, the European Commission, which was also given the exclusive power to submit proposals for measures defining the scope of those rules and the extent to which they apply to production of and trade in agricultural products.

Moreover, while US federal antitrust had to fit into a pre-existing division of competences between the federal and state level, no clear vertical separation of powers existed in EU law, at least until the entry into force of the Treaty of Lisbon. Therefore, while US courts have been unwilling to displace anticompetitive state regulation so as not to upset the federal balance of power, the ECJ faced no similar constraints and, accordingly, had no hesitation in ruling that anticompetitive regulatory measures by EU member states must be set aside if they clash with EU antitrust or internal market provisions.

The role of legal scholarship in shaping the antitrust-regulation interface 
cannot be overstated. In the US, the Chicago School and Harvard School have provided many of the arguments underlying the judicial retrenchment of antitrust from regulated industries, such as the risk of false positives in antitrust enforcement, the inability of courts (as opposed to sector regulators) to effectively monitor certain antitrust remedies, and the limited benefits that antitrust could provide in addition to regulation if applied to certain markets. In the EU, instead, the Freiburg School has insisted on the fragility of competitive markets and the necessity of vigorous antitrust enforcement to preserve their competitive structure. This argument has been conceptualised by the ECJ in terms of a 'special responsibility' borne by dominant undertakings, which may be required to pro-actively assess their conduct under competition law even when their actions are in line with sector regulation. The US private enforcement culture, finally, has prompted courts to raise the liability standard for certain antitrust claims, especially in regulated markets, in order to compensate for an overly aggressive remedies system. No similar over-deterrence concerns have arisen in the EU, where antitrust enforcement is predominantly in the hands of public enforcers. 